\title{
Cultural Features in Alberto S. Florentino's Select Plays
}

\author{
Mardie E. Bucjan \\ Associate Professor at Surigao del Sur State University \\ mardie_bucjan@yahoo.com.ph
}

\begin{abstract}
This paper analyzes the common Filipino cultural features in the select plays of Alberto $S$. Florentino. It aims to determine the non-material components of culture; it specifically focuses in the intangible part of the cultural features such as; norms, values, beliefs and mores of the Filipinos as embedded in the plays. The five prized plays entitled: The World is an Apple, Cadaver, The Dancers, Cavort with Angels, and Oli Impan are the focused on this inquiry. The qualitative research is used in this paper. This study anchored on the framework of Readers-oriented approach. As a general statement; the play manifests the social norm, societal ill like poverty, and value for family. The commoner's lives, belief of Christianity, love and close family ties are among the cultural features found in the play. The five select plays of Aberto S. Florentino manifest the varied cultural features of the Filipino culture such as; norms, values, beliefs and mores of the Philippine society and the Filipino people.
\end{abstract}

Keywords: Filipino culture, norms, values, beliefs, mores, Alberto S. Florentino

\section{INTRODUCTION}

Literature is often said to be the 'window to the world. It is a product of cultures that has a compendious store of information through which learners can gain insights as to the history, traditions and conventions of the target language (Carter \&Long:a) as Cited by (Sidhu and Fook ,2010 ). It is through reading literary texts, learners can get discerning glimpses of a range of cultures and other useful insights that can help broaden one's worldview (Sidhu, 2003) added. Literature fosters an understanding and appreciation of cultures and ideologies, which are different from the learners' native culture. This paper analyzes the common Filipino Cultural features in the select plays of Alberto Florentino. It aims to determine the non -material components of culture; it specifically focuses on the norms, values, beliefs and mores of the Filipinos as embedded in plays of Alberto S. Florentino.

Culutre is the way of life of people.( Hall,1969) as cited by Abubaker. He further quoted American Psychological Association (2002), the belief system and values orientations that influence customs, norms, practices and social institutions. A classic definition of culture according ( Taylor, 1924,) quoted by Reisinger; complex whole which includes knowledge, beliefs, arts, morals , law, customs, and any other capabilities and habits acquired by man as member of society. In the article entitled "Defining Culture and Identities", it says: culture is the totality of the group's thoughts experiences, and patterns of behavior and its concepts, values and assumptions about life that guide behavior and how those evolve with contact in other culture.

In the varying definition of culture from the different viewpoints of experts, this study mainly focusing on the specific norms, values, beliefs and mores of the Filipino culture as depicted in these renowned works of Alberto Florentino. Many researchers, endeavored to analyze the work of Alberto Florentino, based on social themes, plot analyses, conflict and the like, but this paper would be highlighting the cultural features found in the plays which depict the Filipino culture. It is indeed exciting to note how Florentino embed in his winning pieces the very Filipino culture-values, beliefs, norms and mores.

The apt to work on this kind of paper, can inspire educators who have been teaching Philippine Literature-in the DepEd and in the higher education in order to share this knowledge to students the culture of the Filipinos. The literary works of most Filipino writers are innermost which preserve cultural heritage, it leads the students to understand their beginning, manifest concern and assimilate the noble tradition of the culture of their own. 


\section{METHODS}

\subsection{Research Design}

The qualitative research is used in this paper, qualitative research is about exploring issues, understanding phenomenon, and answering questions through analyzing and making sense of unstructured data [qtd from csulb.edu/ msaintg/ppa696/696quali.htm]. This method is the most basic form of investigation which involves the analysis of any unstructured data, including: open-ended survey responses, literature reviews, audio recordings, videos, pictures, social media and web pages. The analysis of the text is the main method used in this paper.

\subsection{Sources of Data}

The study focuses on the selected plays of Alberto S. Florentino. These include the award winning pieces of Florentino. "The World is an Apple", a first prize in the Carlos Palanca Memorial Awards for Literatures in 1953-1954( Drama Division), "Cadaver", first honorable mention in the same Award Winning Body in 1953-1954, "The Dancers," second honorable mention, in 1956-1957 “ Cavort with Angels", first prize in the arena Playwriting Contest in 1958-1959 and "Oli Impan " received an Special Award in the Arena Play writing Contest in 1958-1959 (U.P. Press: 1959) .

\subsection{Data Analysis Procedure}

In reading literary text it always involves the communication between the reader and the text. The reader communicates the text by simply analyzing and interpreting in order to have intelligibility of the text. The understanding of the text is always coupled with appreciating. Appreciation of a literary piece involves literary criticism- the reader's perspective and way of understanding it. The purpose of a literary analysis is to carefully examine and sometimes evaluate a work of literature or an aspect of a work of literature. As with any analysis, this requires you to break the subject down into its component parts. Examining the different elements of a piece of literature is not an end in itself but rather a process to help you better appreciates and understands the work of literature as a whole.

In reading and analyzing literature, literary theories are needed to support the reader in understanding the texts. In support to this claim (Montealegre, 2013 p 227):

" if literary criticism involves the reading, analysis, explication, and interpretation of the texts which are designated as literary, then literary theory should do two things: 1.) it ought to provide the readers with range of criteria for identifying literature and awareness of these criteria should inform critical practice; 2.) it should make the researcher aware of the methods and procedures to employ in the practice of literary criticism, so that you are not only interrogate the text, but also the ways in which you read and interpret the text."

In addition, (Ang,2009p241) mentioned three basic approaches to interpret literature1). TextOriented Approach, (2.)Author-Oriented Approach and, (3.) Reader Oriented Approach. In this study, the researcher anchored on the framework of Readers-oriented approach where the reader may analyze a work of literature by bringing unique set of experience and expectations in extreme form (Ang,2009p243).Specifically the focus of this analysis is the cultural features/patterns such as; norms, values, beliefs and mores of the Filipinos in the select plays of Alberto S. Florentino.

\section{RESULTS AND DISCUSSIONS}

\subsection{The World is An Apple}

Table1. Summary of Cultural Features

\begin{tabular}{|c|c|c|c|c|}
\hline Play Title & Norms & Values & Mores & Belief \\
\hline $\begin{array}{l}\text { The World } \\
\text { is an Apple }\end{array}$ & $\begin{array}{l}\text { Thou shall not steal/ } \\
\text { unacceptable act } \\
\text { Social norm } \\
\text {-Gender role/ things } \\
\text { traditionally done by } \\
\text { women or men } \\
\text {-family rights and } \\
\text { responsibilities }\end{array}$ & $\begin{array}{ll}- & \text { Value for family/ } \\
& \text { Familism } \\
- & \text { Value for love } \\
- & \text { Value for work } \\
\text { - } & \text { Utangnaloob } \\
- & \text { Bahalana } \\
& \text { attitude/kapitsapatalim }\end{array}$ & $\begin{array}{ll}\text { Stealing-un acceptable act } \\
- & \text { Family Structure } \\
- & \text { Father as the head of the } \\
& \text { family } \\
\text { - } & \text { wife stays at home(tends } \\
& \text { the children/does } \\
& \text { household chores/ } \\
\text { domestic affairs) }\end{array}$ & \\
\hline
\end{tabular}


The story started when Mario went home with nothing in his pocket because he lost his job. The couple was on heated argument after Gloria learned that he was fired from the job because of the single apple. Mario valued that apple very much because of Sita's craving for a sweet and delicious apple. It is but normal for a father to think of the welfare of his children. It is a basic need of a child to be loved and valued by his parents. The value for family is depicted in the play, familism is a Filipino trait of patronizing the family above other things, (Leano and Corpuz,p242). On the other hand the Florentino, shows two important things in the life of the person-the work which Mario lost because of the apple and Sita a child who needed his love. In the play the love of a father was deliberately shown through his improper behavior- stealing an apple. The norms says" Thou shall not steal",. In a simple norm of a community such as in a work place, a worker should not take anything outside his work, because it is against from their rules. Mario deviate from the norm stipulated in his workplace; hence, he is liable to his own action. Gloria on the other hand, is right of her feelings that Mario's job is more valuable than a single apple, this belief is true. Every person is entitled to a decent job, just like Mario. But, the problem with him, he violated a certain norm of the society. Stealing is a sin that is why he was punished by law.

Mario's other action, to succumb to his old work with Pablo, is unacceptable act to the mores of the society. The Filipino values which is bahalana attitude or kapit sa patalim, push Mario to go back to his old job. To quote: "Gloria: [Crosses to Mario] Mario... is this what you meant by another job? Oh Mario...you promised me you were through with him. You said you'd go straight.... And never go back to the old kind of life...pp17-18". It is not a right decision that when you are hungry you have to steal in order to feed your hungry stomach, same is true that Mario should not take a move which is against the society norms, because it is unacceptable behavior in the culture of the Filipino people. After Mario have asked help from Pablo, he felt indebted or pagtanaw ng utang na loob as a dominant values of the Filipinos is also depicted in the play. The play manifests the social norm, societal ill like poverty, and value for family. The gender role, the traditional role of a woman and man as a couple such as the father as a head of a family, a wife who stays at home to tend needs of the children and does the household chores or domestic affairs. The family's rights and responsibilities are manifested in the play.

\subsection{The Cadaver}

Table2. Summary of Cultural Features

\begin{tabular}{|l|l|l|l|l|}
\hline Play Title & Norms & Values & Mores & Belief \\
\hline 2. The Cadaver & - Thou shall not & - Envious & Stealing-un & - Belief of Death \\
& steal & - distrust & acceptable act/ & $\begin{array}{l}\text { curse from heaven } \\
\text { - Belief in the } \\
\text { existence of God }\end{array}$ \\
& - -societal ill & - Friendliness & & \\
\hline
\end{tabular}

The knowledge of Marina on the reason of Torio'sillness is related to the kind of work he indulged stealing from the grave of the dead; Marina believed this is a curse from heaven, on taking advantage the dead person in their grave. In the belief of the Filipinos, taking advantage with the unprivileged like the dead is great sin, in the play, the curse from heaven is said to be"karma". Most Filipinos if not all, are believers of Jesus Christ, which everything that he/she does is seen by God in heaven and that sinners most suffer from eternal fire in hell. The prized of sins is death, Torio's death is the prized he got after robbing the dead in the cemetery. In all angles, even if Torio has the reasons for all his actions but it still unacceptable in the mores and norms of land. To quote:

"Torio: I robbed the dead people around us... (Carding, exasperated, sites at doorway and looks out)

Marina: (shocked) what! You mean-

Torio: I was one of those who force open the graves in the cemetery.

Marina: (hardly able to speak) and you stole from them? And you...sold what you found?"

To quote: "Carding: [Sits down] you know what the old folks say about those accidents concerning the dead... Torio: What do they say? Carding: That if one gets wounded-or even only scratched-by the bones of the dead...he will die."- This is a belief of the olds which is depicted in the playCadaver. 
Even then, Torio has reasons of his own-but it does not justify upon committing his sins in order not to be accountable in the end. In the law of the people and God, stealing is a sin and being envious is not good. To quote: "Torio: One night, as I was coming home, A strong rain overtook me. I ran for shelter to the nearest tomb, that one near the road, belonging to a dead millionaire. It was so beautiful. It looked more like a palace than a place for a dead. It had thick marble walls and a roof and festive lights. Inside it was a dead body in a coffin. It was dry in the rain and comfortable even in death. Why should that dead merchant have marble walls and a roof to protect him from the rain, while I was outside, soaked to the bone and shivering, waiting to go home, to a dark, dank place, with a cardboard roof that leaks even in the lightest rain! Why? He's dead and I'm alive! I have more right to the things wasted on him, don't you think so? Don't you think we need thick walls more than the dead?p37

The nature of man to be envious is depicted in the play above; on the other hand, being envious is an acceptable behavior in the norms of the Filipino Culture. Hence, he valued the material things over what he would have in the future, as a consequence of his action he died. The play manifests the commoner's life, poverty of man, and the social ills in general. The Filipino values such as, distrust, friendliness, damayan system and kapitsapatalim are present in the play.

\subsection{The Dancers}

Table3. Summary of Cultural Features

\begin{tabular}{|c|c|c|c|c|}
\hline $\begin{array}{l}\text { Play } \\
\text { Title }\end{array}$ & Norms & Values & Mores & Belief \\
\hline $\begin{array}{l}\text { The } \\
\text { Dancer }\end{array}$ & $\begin{array}{l}\text { Unlawful act/Societal ill } \\
\text { (poverty) } \\
\text { - Family roles/rights and } \\
\text { responsibilities } \\
\text { - Honor thy father and } \\
\text { thy mother }\end{array}$ & $\begin{array}{l}\text { - Filipino value system/ } \\
\text { - Lazy father } \\
\text { - Irresponsible father } \\
\text { - Respect for elders } \\
\text { - Persistence } \\
\text { - Bahalana attitude/ } \\
\text { - kapitsapatalim }\end{array}$ & $\begin{array}{l}\text { - Father as the head of } \\
\text { the family } \\
\text { - adult power over some } \\
\text { decisions } \\
\text { - Eldest son assumes the } \\
\text { responsibilities of an } \\
\text { irresponsible father } \\
\text { - prostitution (taboo) }\end{array}$ & \\
\hline
\end{tabular}

The event is where the more intense scenario is shown to reveal the complication of the play; Florentino tried to show the hardships of a life as a means to reveal the character's behavior. This can be a sad reality that a head of the family who is said to be the defender of his home and family, becomes the advocate of evil- throwing all his children into the muddy life of prostitution in the bar. The lazy and irresponsible father is portrayed in the role of Mang Tomas. In the Philippines the father is the head of the family, the provider and the protector of his own home. The big role of a head of the family is manifested in this play of Florentino. The poverty is shown in the play which opted the other characters succumbed to any kind of job, as long as it earned them money for a living. The Dancers deals with the life of a woman who works in the club and ends up with prostitution. Prostitution is never moral nor acceptable in the society, this is an action which violates moral rules and values of the Filipino community.

The vices of Mang Tomas are manifestations of a lazy father, jobless and irresponsible. For Filipinos, it is expected that a head of the family is a good provided as it is the stereotyped father. The poverty of man is sometimes dependent on the value which deep-rooted from an individual person, just like Mang Thomas. In this play of Florentino, it negates to portray the ideal Filipino father.

\subsection{Carvort with Angels}

Table4. Summary of cultural Features

\begin{tabular}{|c|c|c|c|c|}
\hline $\begin{array}{l}\text { Play } \\
\text { Title }\end{array}$ & Norms & Values & Mores & Belief \\
\hline $\begin{array}{l}\text { Cavort } \\
\text { with } \\
\text { Angels }\end{array}$ & $\begin{array}{l}\text { Unlawful act/Thou } \\
\text { shall not Kill } \\
-\quad \begin{array}{l}\text { Societal ill } \\
\text { ( poverty) }\end{array}\end{array}$ & 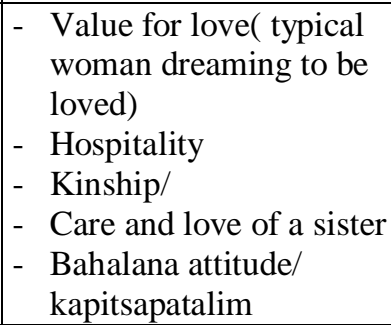 & $\begin{array}{ll}- & \text { (how death is } \\
& \text { viewed)Committing } \\
& \text { suicide is a sin } \\
\text { - } & \text { Cruelty of the world } \\
\text { - } & \text { Prostitution (taboo) }\end{array}$ & 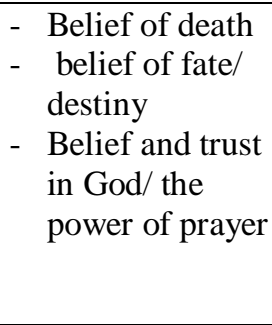 \\
\hline
\end{tabular}


In Florentino's play Cavort with Angels the characters are coming from a lowly family in the society, this is the reality of life which prevailed in the play.The poverty of the commoner's life is present in this play Cavort with Angels. In the social norm, the job( prostitution) of the two sisters is an acceptable. Yes, it gives them life but it is not socially acceptable. In the Filipino culture the work of the sisters are taboo, it does not conform to the value system preserved by Filipinos.

The elder sister is a loving sister who fully understood her situation. She tried to pacify a depressed younger sister who wishes to go out from the world of misery. In most Filipino family, close family ties is evident. The ties of the two sisters after the world war two who became the sole survivor in their family draw them stronger and closer to be in amidst of the miseries of life.

To quote: "Sister: [She sits by her and lays an arm around her.] Don't worry, Lita. Tomorrow we'll give her a good burial. Then you can look for another pet. You can even get another mouse for a pet and I won't mind. I won't try to kill it.[Pause]. Go to sleep, Lita, go to sleep now...p93"

Committing suicide is a sin, in the belief most Filipinos who are Christian, this is a sin in the eyes of God. Taking one's life is unforgivable. This is an immoral act which does not conform to the values, norms and beliefs of the Filipinos.'

The death of any member of a Filipino family is always a big loss. In the play, the elder sister has no one left for her- this seemed to be the end of the world knowing that her sister is her sole strength and an ally in all her endeavors in order to survive. The scenario quoted:"[ The sister rises from her cot, stretches, then goes to the girl and tries to rouse her. She starts on finding her very cold. She calls her several times. Then she sees and picks up the tin can on her lap, realizes she has taken poison, and throws the can away. She screams, kneels down, hugs the girl, and grieves over the body.]"p94.

The love for a sister is immeasurable, among Filipinos; family always comes first. Thus, the play of Florentino, manifest truly the wrath of heaven and the cruelty of life. The poverty, love and close family ties are among the cultural features found in the play.

\subsection{Oli Impan}

Table5. Summary of Cultural Features

\begin{tabular}{|c|c|c|c|c|}
\hline Play Title & Norms & Values & Mores & Belief \\
\hline OLiImpan & $\begin{array}{ll}- & \text {-Societal ill } \\
& (\text { poverty)/ } \\
- & \text {-prostitution }\end{array}$ & $\begin{array}{l}\text { - Love for songs/singing } \\
\text { - Bahalana attitude/ } \\
\text { - Kapit sa patalim } \\
\text { - Friendliness }\end{array}$ & $\begin{array}{l}\text { Gender Role } \\
\text { - Father as the } \\
\text { head of the } \\
\text { family }\end{array}$ & 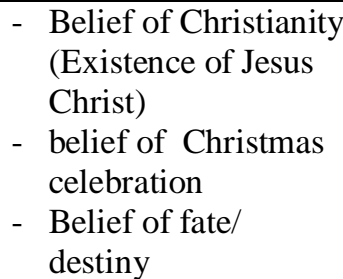 \\
\hline
\end{tabular}

The play started with the introduction of the boy and the girl as the main characters in the play. A sixyear old boy and five year old girl are in the midst of commotion and don't understand what is going on why they are thrown away from their respective houses. The girl wondered whether there was a fire making them move away with their things. In usual cases, exposition is the beginning part of the story.

The demolition team is busy destroying their houses, while a man was fighting against the team and he was captured by the police man. The man was the girl's father. The girl was crying when she saw her father brought by the police car. This is common scenario in big cities like Manila where there are plenty of squatters. The squatters who could hardly live because of lack of permanent job, a social ill that up to the present remain unsolved in the big cities.

The use of song as a style of the author is also seen in this play of Florentino. It gives much meaning to the play since the setting happened four days before Christmas time. The song Silent Night is a perfect style of Florentino to portray the innocence of the two young children who become the victims of their own fate. The song is symbolic; this is used by Florentino to depict a style of his plot which is to signify the unhappiness of the children and the sacrifices of baby Jesus when He was born in the stable of the horses. The children become homeless on Christmas day and Jesus Christ was also homeless when he was born on the same month of December. The use of Biblical allusion is also used by the playwright to add more lessons and meaning to his work- the Oli Impan.

Oli Impan manifests the belief of Christianity, the existence of Jesus Christ and the practice of the Christmas celebration. 


\section{Conclusion}

The five select plays of Aberto S. Florentino manifest the varied cultural features such as; norms, values, beliefs and mores of the Philippine society and the Filipino people.

\section{REFERENCES}

Sidhu, G.K and Fook, C.Y. Instructional Practices in Teaching Literature: Observation of ESL Classroom in Malaysia.[1] (2010)

Sidhu, G.K.. Literature in the Language Classroom: Seeing Through the Eyes of the Learner. In M.E.,[1], (2003)

Abubaker,AInfluence of Core Cultural Values on the Communication Behavior of Staff I Libyan Organisation.[1], (2015)pdf file retrieved on July 20, 2015.

Reisinger ."Conepts of Cross- Cultural Behavior in Tourism"pdf file retrieved on July 20, 2015.[1], 2015

“Defining Culture and Identities"[1] (2015)pdf file retrieved on July 20, 2015

Floretino, A. S(1959). The World is An Apple and Other Prized Plays. Cultural Publishers, Manila, Philippines.U.PPress.Inc.[2],(1959)

Montealegre, E. English: A Reviewer for LET; Philippine Normal University, Metro Manila, Philippines. CalqPublishing, Manila, Philippines.[2], (2013)

Ang, J.G..Kritika Selected Readings in Philippines Lit.from Colonial to Post - EDSA.Mindshapers Co. Inc. 61 Mindulla St. Intramuros,Manila.[2],(2009).

Qualitative Research retrieved from [qtd from csulb.edu/ msaintg/ppa696/696quali.htm][1], (2015)

Kornblum(1991): Sociology in a Changing World Second Edition,p99[1](1991)

http://vcampus.uom.ac.mu/soci1101/221the_components_of_culture_symbols_language_values_and_ norms.html

Leano and Corpuz, M.R. Society and Culture with Family Planning. [2](2012)

\section{AUTHOR'S BIOGRAPHY}

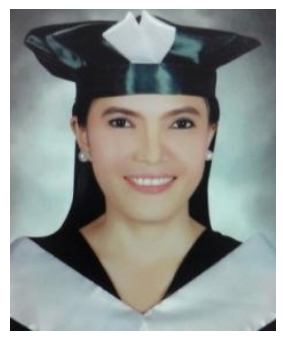

Dr. Mardie E. Bucjan

Associate Professor IV

Doctor of Philosophy in English major in Literature

Doctor of Eduation major in Eduational Management

Faculty in the College of Business and Management, Surigao del Sur State University

Affiliate Faculty Graduate Studies, Surigao del Sur State University

Research Coordinator, Graduate Studies

Teaching English Language and Literature

Resource Speaker on School Based Action Research and Current Trends in

Research

Trainer -Regional Mass Training for Grade 9 and 10 English Teachers in CARAGA Region 